UDC 636.182(497.7)"2017/2018"

Original research paper

doi: 10.5937/AASer1846213B

Acta Agriculturae Serbica, Vol. XXIII, 46 (2018); 213-221

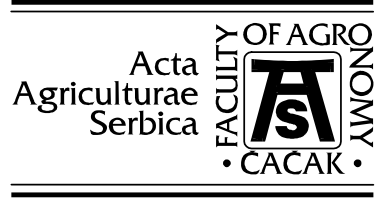

\title{
Defining breed standards and breeding goals for domestic donkey
}

\author{
Gjoko Bunevski $^{1^{*}}$, Jelena Nikitovic ${ }^{2}$, Marjan Janzekovic ${ }^{3}$, \\ Andrej Mergedush $^{3}$, Jernej Prishenk ${ }^{3}$, Boge Trajkovski ${ }^{4}$, Marina \\ Antić ${ }^{2}$ \\ ${ }^{1}$ Institute of Animal Biotechnology, Faculty of Agricultural Sciences and Food, \\ 16-ta Makendska brigada 3, 1000 Skopje, Macedonia \\ ${ }^{2}$ Institute of Genetic Resources, University of Banja Luka, Bulevar vojvode Petra \\ Bojovica 1a, 78000 Banja Luka, B\&H \\ ${ }^{3}$ Faculty of Agriculture and Life Sciences, Pivola 10, 2311 Hoče-Maribor, \\ Slovenia \\ ${ }^{4}$ Association of Horse Farmers “Golden Shoe”, v. Novo Selo, Skopje, Macedonia \\ *Corresponding author: bunevski@gmail.com
}

\begin{abstract}
Domestic donkey is a transboundary breed present in many Balkan countries. According to the Law on Animal Production, in many Balkan countries, for every breed of domestic animals it is necessary to create a separate breeding programme. Based on the results of a study evaluating the main morphological, reproductive and functional traits in 47 domestic donkeys in Macedonia during 2017 and 2018, current standards and breeding goals were defined for the next national breeding programme of this breed. According to the fact that the domestic donkey is a metapopulation and transboundary breed in almost all Balkan countries, it is a good recommendation to create a regional breeding programme with flexible standards and breeding goals for this relative of horses for all Balkan countries together.
\end{abstract}

Keywords: donkey, domestic breed, breeding goals and standards, selection. 


\section{Introduction}

Domestic donkey is a member of the equine family, including horses, mules and zebras. The donkey is a domesticated member of the horse family - Equidae. The wild ancestor of the donkey is the African wild donkey -E. africanus. The donkey has been used as a working animal for at least 5000 years. There are more than 40 million donkeys in the world, mostly in undeveloped countries, where they are used principally as draught or pack animals. Working donkeys are often associated with those living at or below subsistence levels. Small numbers of donkeys are kept for breeding or as pets in developed countries. For centuries donkeys have been used by humans for various reasons such as for work, milking, breeding and eating. Donkeys are very gentle, affectionate, intelligent, cautious and brave. Donkeys adopt a protective attitude to vulnerable groups of people, children and people of reduced mobility. They can also be used as companion animals. Different geographic and climatic conditions have resulted in the creation of different kinds of donkeys in different countries even in different regions.

All Balkan countries have demonstrated their commitment to the conservation and sustainable use of biodiversity, including agricultural biodiversity, by ratifying the Convention on Biological Diversity. The main goal of FAO (The Food and Agriculture Organization of the United Nations) is to alleviate poverty and hunger by promoting sustainable agricultural development, improved nutrition and enhanced food security. Agricultural biodiversity, including livestock diversity, underpins food security, provides the basis of many economic activities and is important to ecosystem functioning. In response to the challenges identified in The State of the World, the international community adopted the Global Plan of Action for Animal Genetic Resources in 2007. It includes 23 strategic priorities for action grouped into four priority areas: characterization and monitoring; sustainable use and development; conservation; and policies, institutions and capacity-building. This publication contributes in an excellent way to the implementation of the Global Plan of Action by raising awareness of the roles and values of our state animal genetic resources, describing threats to indigenous breeds of livestock and the importance of indigenous breeds for the maintenance of landscapes, habitats and wild biodiversity. Almost all Balkan countries implementing the Global Plan of Action have prepared their National Programmes for the Protection of Native and Protected breeds of Domestic Animals.

Every Breeding programme for autochthonous breeds, as well as for domestic donkey, ought to define the following aspects: rearing area, breeding structure and population size, as well as their specific breeding goals, breeding standards, breeding methods and separate selection programmes for these breeds. 
The Balkan domestic donkey originates basically from two ancestors: 1) the Namibian donkey (Equus asinus africanus), and 2) Somalian donkey (Equus asinus somaliensis). The small variety of the domestic donkey from Macedonia, Serbia, Bosnia and Herzegovina, and Montenegro, and the Dalmatian type from Croatia and Slovenia mainly originate from the small ancestor - the Namibian donkey.

The domestic Balkan donkey is reared mainly in the hillymountainous areas of the Balkan Peninsula (Trailovic, 2009). During the XX century, the total number of donkeys permanently decreased, because of a decreased interest in their rearing, as well as because of depopulation in mountain villages. In the last few years, the interest in the domestic donkey has increased again after several decades, according to the Interlaken Declaration and FAO recommendations for the conservation of local domestic breeds in the world. Therefore, the starting investigation is aimed at phenotypic characterization, inventory and preparation of breeding objectives and standards for this breed.

Balkan donkeys are bred and used primarily in regions with the Mediterranean climate, and to a lesser extent in Continental and Mountain climates, along seacoasts, continental lakes and mountain rivers in areas with insufficient food and water supplies, where it is not possible to keep other work animals (cattle and horses). Karst landscapes, fragmented arable surfaces, poor roads, larger percentage of crops requiring hoeing (vegetables, grapevines, fruit), and lack of high quality feed have made donkeys the most appropriate work animals in island and coastal villages as the result of their resistance, endurance and undemanding nature.

\section{Biodiversity programme for domestic donkey in Macedonia}

The National Biodiversity programme in Macedonia started in 2014. In horse breeding, a special emphasis was given to 1. the Domestic Mountain horse, and 2. the Domestic donkey. The programme is implemented through the following activities: phenotypic characterization of adult male and female donkeys, inventory and conservation of the genetic material. Unfortunately, still, the main problem for registration is identification of all donkeys in Macedonia, as donkeys are the only species of domestic animals which are not registered and identified.

Theoretically, the breeding goal is the directed genetic improvement of certain characteristics realized in successive generations of animals which accomplish the desired production through future, but expected economic, social and ecological production conditions (Groen, 2000). The clear definition of breeding goals means what we have to expect in the future. Therefore, defining breeding goals is the first step of every breeding programme for each breed of donkey. But for each productive type and breed of donkeys, there are different separated breeding objectives, depending on zoo technical, economical and 
market conditions. From the farmers' point of view, every breeding goal ought to satisfy 2 main conditions: 1) maximal profit under current productive conditions, and 2) minimize the realization risk within working limits (Groen, 2000, Drumi, 2011, Mitrovic, 2011). According to the breeding goals, the next breeding and selection programme ought to be adapted for each breed of domestic donkey, with the emphasis on defining traits, aggregate genotype, variances, covariances, fixed and random effects, heritabilities and other parameters. Finally, all breeding goals are directly or indirectly associated with the profit function on the farm; therefore, they have an economical value.

\section{Material and methods}

The phenotypic characterization of adult domestic donkeys belonging to the Macedonian variety was performed in several mountain villages, as shown in the following table.

Table 1. Total number of domestic donkeys subjected to phenotypic characterization in Macedonia in 2017 and 2018

\begin{tabular}{|c|c|c|c|}
\hline & Location & Species/breed & $\begin{array}{c}\text { Total number of } \\
\text { animals }\end{array}$ \\
\hline 1. & V. Visoka Mala & Domestic donkey & 13 \\
\hline 2. & V. Velestovo & Domestic donkey & 10 \\
\hline 3. & V. Breznica & Domestic donkey & 9 \\
\hline 4. & V. Barbarevo & Domestic donkey & 6 \\
\hline 5. & V. Kuratica & Domestic donkey & 9 \\
\hline & \multicolumn{2}{|c}{ Total number: } & 47 \\
\hline
\end{tabular}

Two national autochthonous equidae species (domestic mountain horse and domestic donkey) are still outside the national subsidy programme, mainly because of the lack of identification of donkeys in the state. According to the results on the phenotypic characterization of adult domestic donkeys in mountain parts of Macedonia, the following standards and breeding goals are proposed.

The main breeding objective for domestic donkey is to conserve the breed to prevent its extinction from the region, and ensure economical and sustainable production in hilly and mountainous areas. This can be achieved by control, entry into registry, proper identification and registration according to the EU 
regulations, selection by male and female lines and improvement of their morphological, productive, reproductive and functional traits.

\section{Results and Discussion}

According to obtained results on the control of 47 domestic donkeys in several villages in mountainous parts of Macedonia in 2017 and 2018, the main proposed standards for the Macedonian type of the domestic mountain donkey are shown in Table 2.

Table 2. Standards for the Macedonian type of the domestic donkey

\begin{tabular}{|c|c|}
\hline Parameters & Standards (average value) \\
\hline Height of withers (cm) & $104(88-122)$ \\
\hline Height of back and loin (cm) & $106(90-124)$ \\
\hline Body length (cm) & $110(98-126)$ \\
\hline Chest circumference $(\mathrm{cm})$ & $113(100-126)$ \\
\hline Chest height $(\mathrm{cm})$ & $30(25-40)$ \\
\hline Chest depth (cm) & $40(35-50)$ \\
\hline Cannon circumference $(\mathrm{cm})$ & $12(10-15)$ \\
\hline Body mass (kg) & 90 (females) to 100 (males) \\
\hline Coat Colour & Brown, black and grey \\
\hline Ramp & Oblique and round \\
\hline Chest & Deep and not particularly wide \\
\hline Head & $\begin{array}{c}\text { Heavy and dry, with a straight face profile and a length } \\
\text { of } 40-45 \mathrm{~cm}\end{array}$ \\
\hline Neck & Short and muscular, flat withers \\
\hline Shoulders & Long and inclined \\
\hline Back & Mainly straight \\
\hline Quarters & Sloping \\
\hline Legs & $\begin{array}{l}\text { Short and muscular, with broad joints and strong } \\
\text { tendons }\end{array}$ \\
\hline Gaited & Well movement, sure-footed \\
\hline Constitution & Strong constitution and good health \\
\hline Fertility & Very good \\
\hline Adaptation and acclimatization & Excellent, well adapted to in harsh environments \\
\hline Longevity & Relatively long \\
\hline
\end{tabular}


When the main reproductive traits of domestic donkeys are compared acrossBalkan countries, similaries are found with the neighbouring countries (Mesaric et al., 2015, Trailovic et al, 2011), but the Macedonian type of the domestic donkey has smaller values for morphological traits mainly due to natural environmental conditions.

Concerning the breeding objectives for the next Breeding Programme for Domestic Donkey, the general objectives for the Macedonian variety of domestic donkey are:

- Conservation of the breed - genotype,

- Conservation and improvement of the quality of domestic donkeys,

- Incorporation of donkeys into rural development and agritourism,

- Using the domestic donkey for recreational purposes and climbing (alpinism),

- Production of quality meat and milk products from donkeys,

- Improvement of domestic donkeys with good character, calm temperament and regular fundament, and

- Increasing the body frame and body weight in domestic donkeys.

According to the breed standards, the main breeding goals for the domestic donkey in Macedonia are presented in Table 3.

As regards the morphological traits, the main emphasis is given to selecting bigger animals (with more than $105 \mathrm{~cm}$ of wither height) with large and long bodies, which can consume big amounts of forage crops. Legs ought to be thin, and with strong healthy hooves. As regards functional traits, especially desirable are animals characterized by good resistance to diseases, good endurance, good fertility, early maturing, easy delivery, and good growth (daily gain). Young mares should have faster development and approximately $90 \mathrm{~kg}$ of body weight at 24 months of age.

Additional activities for improving the sustainable production and rearing of domestic donkeys could be:

- Cryoconservation of breed ex-situ,

- Improving quality traits in donkeys,

- Taking part in programmes for rural development, agritourism, recreational purposes and climbing,

- Taking part in programmes for hippotherapy and medical tourism,

- Improving daily and meat performances of donkeys for the production of some traditional products, etc. 
Table 3. Main breeding objectives for the domestic donkey in Macedonia

\begin{tabular}{|c|c|}
\hline Parameters & Breeding goals \\
\hline Main breeding goals & $\begin{array}{c}\text { Conservation of the genotype and increasing the percentage } \\
\text { of purebred animals under control }\end{array}$ \\
\hline $\begin{array}{l}\text { Height of withers } \\
\text { (male/female) }(\mathrm{cm})\end{array}$ & $100 / 110$ \\
\hline Height of back and loin $(\mathrm{cm})$ & $112-114$ \\
\hline Body length $(\mathrm{cm})$ & $115-120$ \\
\hline Chest circumference $(\mathrm{cm})$ & $120-130$ \\
\hline Chest wight $(\mathrm{cm})$ & $30-35$ \\
\hline Cannon circumference $(\mathrm{cm})$ & $13-15$ \\
\hline Chest depth (cm) & $45-55$ \\
\hline Coat Colour & Brown, black and grey, rarely chestnut, bay, dun \\
\hline Rump & Oblique and round \\
\hline Neck & With middle length, strong and muscular \\
\hline Fundament (legs) & $\begin{array}{c}\text { Strong, dry with correct position, muscular with strong } \\
\text { ligaments and hooves }\end{array}$ \\
\hline Chest (barrel) & Strong constitution and good health \\
\hline Head & Small and dry, with plate face profile \\
\hline Body weight of mares & $100-110 \mathrm{~kg}$ \\
\hline Body weight of stallions & $110-130 \mathrm{~kg}$ \\
\hline Constitution & $\begin{array}{c}\text { Strong constitution and excellent health, with excellent } \\
\text { endurance }\end{array}$ \\
\hline Fertility & Excellent \\
\hline $\begin{array}{l}\text { Adaptation and } \\
\text { acclimatization }\end{array}$ & $\begin{array}{l}\text { Excellent, with good natured temperament and docile } \\
\text { personality }\end{array}$ \\
\hline Longlasting & Relatively long \\
\hline $\begin{array}{l}\text { Other important functional } \\
\text { traits: }\end{array}$ & $\begin{array}{l}\text { Bigger capacity for growing, better working ability, } \\
\text { larger body frame, as well as other traits related to their } \\
\text { resistance, good milk and meat quality, sustainability, } \\
\text { longlasting and efficiency. }\end{array}$ \\
\hline
\end{tabular}

Breeding methods for domestic donkeys

The main recommended method of breeding domestic donkeys is breeding in pure breed (pure race). It can be: a) very close, b) close) and c) moderate. The first two submethods are very risky and could be harmful if they are out of 
expert control, if they lack good selection of parents and good rearing conditions. Particular importance is given to inbreeding coefficients and depression in a controlled population (Baban, 2011, Trajkovski and Bunevski, 2007).

Every breeding programme involves the following steps: 1) defining breeding goals, 2) defining the breeding programme, 3) defining selection criteria, 4) creating a breeding scheme, 5) creating a breeding structure, 6) creating a mating plan, 7) progeny control, and 8) economic analyses of the breeding programme.

According to the Law on Animal Production (2008), the Common Breeding Programme for Livestock Selection (CBPLS) was prepared in 2010 by the Ministry of Agriculture. The breeding programme for domestic donkeys takes account of a lot of traits which are divided into several groups: a) Productive and reproductive traits, b) Exterior traits, c) Linear traits, d) Other functional traits (Ivankovic et al., 2014, Trailovic, 2011).

\section{Conclusions}

According to the controlled traits and results of morphological and reproduction traits in 47 domestic donkeys in mountain parts of Macedonia, breeding standards and breeding goals were defined for the future breeding programme for indigenous breeds - domestic donkeys in Macedonia. According to the fact that the domestic donkey is a metapopulation and transboundary breed of donkeys in all Balkan countries, it is a good recommendation to create a regional breeding programme with flexible standards and breeding goals for this breed from Slovenia, Croatia (along with the established International Breeding Programme for three types of Croatian donkeys), Bosnia and Herzegovina, Serbia, Montenegro, Albania, Greece, Bulgaria, Turkey and Macedonia.

\section{References}

Baban M., Sakac M., Korabi N., Antunovic B., Mijic P. (2011): Horse breeding and selection in the Republic of Croatia. Proceeding - Horsevile 2011, $2^{\text {nd }}$ Fair of horse breeding: 54-60. Belgrade.

Belic J. (1991): Album rasa stoke. Beograd.

"Breeds from species: Ass". Domestic Animal Diversity Information System. Food and Agriculture Organization of the United Nations (FAO). Retrieved April 28, 2016.

Clutton-Brock J. (1987): A natural history of domestic mammals, Vol 2, Cambridge University Press, Cambridge.

"DAD-IS - Domestic Animal Diversity Information System". Food and Agriculture Organization of the United Nations. Retrieved June 1, 2011.

Ensminger M.E. (1991): Animal Science. Interstate Publishers, INC Danville, Illinois.

Epstein H. (1984): Ass, mule and Onager. In Mason IL (ed) Evolution of Domesticated Animals. Longman, London and New York. 
FAO (2007): The State of the World's Animal Genetic Resources for Food and Agriculture, ed Barbara Rischkowsky \& Dafydd Pilling. Rome.

French J. (1997): "Social Behaviour", in Elisabeth Svendsen (ed.), The professional handbook of the donkey, 3rd edition. London: Whittet Books: 127-165.

Groen A. (2000): Breeding goal definition. In "Developing breeding strategies for lower input animal production environments". ICAR, No 3.

Hermsen J. (2004): The Complete Encyclopedia of Horses. The Netherlands.

Hrvatski stocarski centar (2004): Konjogojstvo, Zagreb.

Ivankovic A., Klemen P., Ramljak J., Baban M., Neven A. (2014): Mlijeko kobila i magarca, 1-158. Zagreb.

Clutton-Brook J. (1999): A Natural History of Domesticated Mammals.

Livestock Of The World. "About Donkeys Breeds of Donkeys". www.livestockoftheworld.com. Retrieved January 23, 2017.

Mitrovic S., Dzermanovic V., Trailovic R., Trailovic D. (2011): Equine selective breeding in Serbia: Status and perspectives. Proceeding - Horsevile 2011, Belgrade. $2^{\text {nd }}$ Fair of horse breeding: 47-53.

Pejić N. (1996): Konj-Equus Caballus. Novi Sad.

Rossel S, Marshall F et al. (2008): Domestication of the donkey: Timing, processes, and indicators. Proceedings of the National Academy of Sciences, 105 (10): 3715-3720.

Shmalcelj I., ogrizek I. (1955): Konjarstvo. Zagreb.

Starkey P. (1997): "Donkey Work", in Elisabeth Svendsen (ed.), The professional handbook of the donkey, 3rd edition. London: Whittet Books: 183-206.

Svendsen, Elisabeth (ed.) (1997): The professional handbook of the donkey, 3rd edition. London: Whittet Books: pp. 208.

Trailović R. (2009): Filogenetska proučavanja domaćeg brdskog konja na osnovu genetskih markera. Doktorska disertacija, Univerzitet u Beogradu: Fakultet veterinarske medicine, Beograd, 2009.

Trailovic R., Ivanov S., Djokovic S., Trailovic D. (2011): Morphological characteristics and health status of Yugoslav Mountain pony in reservation park Stara Planina. Proceeding - Horsevile 2011, Belgrade. $2^{\text {nd }}$ Fair of horse breeding: 175-179.

Trajkovski T., Bunevski Gj. (2007): Horse breeding (book): 1-271, Skopje.

Waltraud K.; Hans-Peter G.; Elli B. (2008): Donkey Breeds in Europe: Inventory, Description, Need for Action, Conservation; Report 2007/2008 (PDF). St. Gallen, Switzerland: Monitoring Institute for Rare Breeds and Seeds in Europe. Archived from the original (PDF) on 2 September 2009.

https://www.researchgate.net/publication/263443107_Domesticated_Donkeys__Part_II_Types_and_Breeds 